\title{
The applicability of the 'Japanese management style', to the South African context: Preliminary Research
}

\author{
Linda Human and Leonie le Roux \\ School of Business Leadership, University of South Africa, Pretoria
}

\begin{abstract}
This introductory study of the applicability of the 'Japanese management style' to the South Atrican context highlights a number of important issues relating to the study of Japanese economic progress and to the applicability of 'Japanese management methods to other contexts. It atso questions the otten-held assumption that the so-calted 'Japanese methods' are so very dif. ferent from those employed in the West.

This article subsequently takes a look at the core workforce in Japan in relation to some research findings with regard to certain South African companies within which quatity control circles are in use or are planned for the future. In so doing, it highlights certain problems relating not only to the delimitation of the 'Japanese' style but also its applicability to a context of culturat heterogeneity. In other words, this research questions the extent to which techniques of management which have proved suc. cessful in a relatively stable, equal, homogeneous and educated culture can be applied in a culturally and educationally heterogeneous society in which one particular group dominates the remainder.

S. Afr. J. Bus. Mgmt. 1983, 14: 131-139
\end{abstract}

Hierdie inleidende studie oor die toepasbaarheid van die 'Japanese bestuurstyt' binne die Suid-Afrikaanse konteks beklem. toon 'n aantal belangrike aangeteenthede wat verband hou met die bestudering van Japanese ekonomiese vooruitgang en die toepasbaarheid van 'Japanese' bestuursmetodes binne ander kontekste. Dit bevraagteken ook die algemene aanname dat hier. die sogenaamde 'Japanese metodes' soveel verskil van dié wat in die Weste gebruik word.

Die artikel kyk vervolgens na die kern werkersmag in Japan met betrekking tot sommige navorsingsbevindings in verband met sekere Suid.Afrikaanse maatskappye waarbinne kwaliteitskontrolesirkels toegepas word of wat die toepassing daarvan vir die toekoms beoog. Sodoende word sekere probleme rakende nie net tie afbakening van die 'Japanse styl' nie, maar ook die topasbaarheid daarvan binne 'n kultureel-heterogene konteks uitgelig. Met ander woorde, hierdie navorsing bevraagteken die mate waarin tegnieke wat suksesvol bewys is in 'n relatief stabiele, gelyke, homogene en ontwikkelde kuttuur toegepas kan word in 'n samelewing wat heterogeen ten opsigte van kultuur en ontwikkelingspeil is en waarbinne een spesifieke groep die res domineer.

S.Afr. Tydskr. Bedryfsl. 1983, 14: 131- 139

\section{Introduction}

Since World War II, Japan, a small country with few natural resources, has made meteoric progress within the world economy, shattering the complacency of American and European managers who formerly dominated not only domestic but also a large percentage of foreign markets. Managers and academics in the West - bewildered by the Japanese challenge - have sought to understand and explain the phenomenal ascendancy of this, their most powerful rival. As Drucker' states

'To many business people and public officials in the

West, the postwar success of the Japanese economy is

both an impressive and a puzzling achievement. The success is obvious and measurable; the reasons for it, far less so.'

The various attempts to understand and explain the growth of the Japanese economy display a number of distinguishing characteristics which tend to vary according to points of emphasis. For example, some explanations focus on Japan's distinct socio-cultural background (Abegglen; ${ }^{2}$ Caudill \& Scar; ${ }^{3}$ Yoshino; ${ }^{4}$ Redding; ${ }^{5}$ Bartels ${ }^{6}$ ); others focus more specifically on work-related values (Johnson \& Ouchi; ${ }^{7}$ Kraar; ${ }^{8}$ Kotler \& Fahey; ${ }^{9}$ Asakura ${ }^{19}$, others have sought for understanding in differing managerial techniques (Drucker; ${ }^{11}$ Cooper \& Kuniya; ${ }^{12}$ Hatvany \& Pucik; ${ }^{13} \mathrm{Lim}^{14}$ ). Still others would argue that, although a better understanding of lapanese culture and society has been gained through these studies, discussions of Japanese and Western management methods have led to unrealistic stereotypes and to overgeneralization, (Cole; ${ }^{15}$ Thurley ${ }^{16}$ ).

'Participant-observation approaches in Japan, for example, reveal that specific organizations are far removed from the common characterization of Japanese organizations - that of being human relations-oriented social clubs bestowing extensive fringe benefits and bonuses upon lifetime employed members in a noncompetitive environment characterized by advancement by seniority', (Reitsperger ${ }^{17}$ ).

Indeed, Clark' ${ }^{18}$ study of a Japanese company reveals a high stress level as a result of discipline, a fiercely competitive environment and a 'superficiality' of human relations. To take just one other example out of many, Marsh and Mannari ${ }^{19}$ argue that the differences in motivational dispositions between Japanese and Western workers have been exaggerated.

Many of these findings, however, relate specifically to Japanese companies operating in Japan and not to Japanese organizations functioning in other countries of the world or 
to the utilization of so-called 'Japanese methods' by companies with no other ties with Japan. With respect to Japanese companies operating in other countries of the world, a number of studies have come up with conflicting findings with regard to the efficacy of the Japanese 'human relations' approach and its contribution to 'better' management whilst Johnson ${ }^{22}$ found that in those organizations within which such methods were already in existence, productivity and satisfaction were no higher than in their American counterparts (Reitsperger ${ }^{23}$ ). Reitsperger's ${ }^{24}$ study of Japanese television manufacturers in the UK highlights the fact that, although the Japanese manufacturers interviewed achieved superior quality and productivity performance in comparison with a local company and an American multinational operating in the UK, distinctly different approaches between the Japanese companies in the UK exist.

'Significantly, human relations' emphasis in one of the Japanese companies has not led to superior performance over its matched Japanese counterpart, which places no emphasis on human relations. The most pronounced human relations' emphasis, in fact, existed in the American multinational company and this, in turn, did not reflect higher performance levels. It seems that the single-minded pursuit of productive performance improvement in both Japanese companies, which was expressed in the design of the task structure, technological adjustments, performance feedback, and a reward system geared toward performance improvement and an appropriately designed supervisory role and style were key variables in building the operators' competencies necessary to achieve superior quality and productivity performance to the local and American counterpart' (Reitsperger ${ }^{25}$ ).

Reitsperger ${ }^{26}$ argues that the distinct differences between the Japanese companies in leadership style, in the characteristics of their personnel and in the technology and task structures they employ all indicate distinct corporate cultures. Like Thurley ${ }^{27}$, Reitsperge ${ }^{28}$ therefore concludes that the stereotypes of a 'Japanese style' are inadequate and that organizational form bears no more than a flexible relationship with organizational goals even when a number of organizations operate under essentially identical environmental conditions.

The essence of Reitsperger' ${ }^{29}$ argument is that the Japanese companies observed have proved themselves as superior producers not by an emphasis on human relations but rather by component organizational engineering. But what about those 'foreign' companies which employ certain 'Japanese' management techniques? Are these companies more successful than their rivals who employ techniques derived from the West? And if so, are they more successful because of an emphasis on human relations or rather because of competent organizational engineering?

The purpose of this article is to take a look at some of the companies which seem to be employing so-called 'Japanese' management tecniques within the South African context. None of these companies are of Japanese origin; nor does any company employ Japanese personnel. What these companies have in common is a tendency to display certain managerial characteristics which could be subsumed under the broad heading of 'Japanese'. In examining these companies in detail, this research will argue against many of the popular images of Japanese management practices and against easy interpreta- tions of Japanese culture. In other words, an attempt will be made to provide a realistic account not only of Japanese culture but also of its influence on managerial systems regarded as typically Japanese. Subsequently, an attempt will be made to assess the utilization of so-called Japanese management techniques in South Africa in the light of these accounts.

\section{Japanese culture}

Japanese culture originated from the Jomon culture which dates back at least 9000 years. The Jomon period saw the commencement of agriculture in Japan and was an era marked by its vigour and vitality. Subsequently, the peaceful Yayoi period, which began approximately 2300 years ago, saw increasing agricultural productivity, an increasing appreciation of nature in art and the accompanying contemplation of the harmony and perfection of the natural order (Forss et al. ${ }^{39}$ ).

Approximately 800 years later, the Yamato culture was imported from China via Korea and served as a means of unify. ing the islands of Japan and of dominating the warring feudal lords. This cultures was built on the Confucian ideal of society and both the concept of duty and the establishment of the samurai class appear to stem from this time. However, the wars of the sixth century led to an influx of refugees into Japan and included Buddhist artists and artisans. Shotoku Taishi, the Japanese ruler of the time - a leader struggling with a lack of hegemony amongst the royal family and almost complete equality between clans and feudal lords - saw in Buddhism the opportunity to consolidate the sovereign power of his family. The Buddhist idea of truth and of the enlightened spirit of humanity provided a universal basis for the relationship between the ruler and the ruled. Harmony was considered to be the overriding social objective at the expense of competition and conflict. The natural order - which was 'good and right' - set out one's proper station in life whilst the Confucian idea of Heaven, Earth and Man established the central authority of the court, (Forss et al. ${ }^{31}$ ).

At the same time, however, Confucianism, which reached Japan in the early fifth century, was also to have many important consequences for Japanese culture. Indeed, Confucianism has had a profound influence on Japanese morals and views of life and probably still exerts a good deal of influence today. In essence, Confucian philosophy originates from the Chinese Ju Chiao or 'the Teaching of the Learned'. Confucius was revered as the great sage of the cult but other scholars have shared in its development and other schools of thought, such as Buddhism and Taoism, have strongly influenced its development. The aim of Confucius was to create an orderly and stable society which would replace the feudal chaos of the time. To this end, Confucianism concerns itself with the harmonious organization of the society and of the state, with man's relation to man and with the nature of man and the universe and their relation to each other. Confucianism is not only a religious but also a social and political doctrine; it permeates all aspects of man's life on earth, (Smedley ${ }^{32}$ ).

These three cultures then - the Jomon, the Yayoi and the Yamato - eventually began to exist side by side and indeed still co-exist today. As Benedict ${ }^{33}$ states:

'All these contradictions, however, are the warp and woof of books on Japan. . . Both the sword and the chrysanthemum are part of the picture. The Japanese are, to the highest degree, both aggressive and unaggressive, both militaristic and aesthetic, both insolent and polite, rigid and adaptable, submissive and resentful of being pushed around, loyal and treacherous, brave 
and timid, conservative and hospitable to new ways.' or, according to Forss et al., ${ }^{34}$

'If one can talk about a common denominator in the studies of Japan, it is puzzlement by the seeming contradictions among the Japanese, as for example: flexibility and rigidity, traditional and modern.'

Knowledge of the ancient cultures of Japan, however, helps us to understand these seeming contradictions and conflicts and affords us the opportunity to trace the origins of the many opposing findings with regard to 'Japanese' management techniques. For example, the Yamato culture was hierarchical and emphasized rigidity and stable social relations whereas the preceding Yayoi period, although conservative, was far more flexible with regard to the absorption of ideas developed dsewhere. The Jomon culture, on the other hand, was dynamic and vital and displayed an eager ability to adapt and change. These diverse cultural traits are, in turn, held together by metaprinciples, inherited from the Jomon and Yayoi cultures, which see virtue in diversity, in change and in the interaction between heterogeneous parts, (Forss et al. ${ }^{35}$ ).

The diverse cultural traits which the Japanese have inherited from the various cultures on which their civilization is based have led to the development of specific thought traditions relating to direct experience and indirect thinking. There exists a tendency for the Japanese to simply accept life as it is, with all its confusions, incompatibilities and contradictions. According to Moore, ${ }^{36}$ conceptual, analytic and explanatory thought are regarded as escapist; immediate experience and intuition are perceived as the bases for understanding reality as it 'really is'. As Suzuki states:

'The Western mind abhors paradoxes, contradictions, absurdities, obscurantism, emptiness, in short, anything that is not clear, well defined, and capable of determination. To the Far East, these are not to be adhorred; in fact, they represent reality as it is - and truth. Its emphasis is always on the concrete - and directness of living.' (see Forss et al. ${ }^{37}$ )

Japanese culture and thought, like those of the Chinese, are basically eclectic and have retained the ability to assimilate seemingly contradictory elements within a single structure. This ability is, moreover, nowhere better demonstrated than in those values traditionally regarded as 'typically Japanese'. Let us take a brief look at a number of these values as their relationship to so-called 'Japanese' management systems is of some considerable importance.

\section{Collectivism}

In Japanese culture, the individual is subordinate to the group and group activity is what makes 'individual' life meaningful $\left(\right.$ Moore $\left.{ }^{38}\right)$. 'The basis for the relationship to a group is the obligations of the individual; the emphasis is on duty and loyalty, not on rights,' (Forss et al. ${ }^{39}$ ).

\section{Obligations, responsibility and authority}

The Japanese individual possesses a network of obligations to all of the groups of which he is a member, together with an indebtedness towards his parents, forefathers, teachers, leaders, employers and nation. Righteousness is thus defined as a recognition of one's obligations and of one's place in life and one must constantly work on the repayment of one's indebtedness. These obligations and duties manifest themselves in certain ways such as in loyalty to the family, to the company and to the nation and in a commitment and a feeling of indebtedness towards groups (Forss et al. ${ }^{40}$ ).
In view of the importance of group life, individual responsibility takes second place to group responsibility. However, the distinction between individual-and group responsibility is somewhat vague as group responsibility depends on individual commitment; there would be no group responsibility in the absence of individual commitment to the group.

Be that as it may, within organizations, joint responsibility for a task replaces descriptions of individual responsibility. In other words, individual responsibility for a task is replaced with responsibility towards the group and the group task. Group members appear to have a stronger sense of responsibility towards smaller than larger groups and will accept the dependence of weaker groups should assistance be required. Authority, in turn, is primarily based on the character, status, prestige or title of the person rather than the right of certain individuals under certain circumstances to issue orders. Put in another way, authority derives from the character of the person involved and not from 'who has authority over whom and what'. This Western perception of authority has had litthe influence on organizational life in Japan (Forss et al. ${ }^{4 I}$ ).

\section{Hierarchy and egalitarianism}

In Japanese history, social differentiation according to wealth has generally been regarded as insignificant although the Japanese are conscious of delicately-graded rankings which are based on power. The authority of a person stems from his personal characteristics as opposed to his wealth. Indeed, very small income differences suffice to highlight inequality and act as motivators in competitive situations (Forss et $a l^{42}$ ).

\section{Official stance versus true intentions}

As stated earlier, one of the underlying principles on which the Japanese value system rests is the subordination of the individual to the group. To this end, the individual sacrifices his own wishes to the good of his family, his work group and his company. Obviously, such sacrifices are a potential and potent source of conflict which could lead to a malfunctioning of the group as a whole. To avoid problems such as these, in Japanese group life, the individual will keep relations on a 'tatemae' (front face or official stance) level. Only in relatively secure situations, will his 'honne' or true intentions be revealed. The inherent 'dishonesty' in tatemae is accepted as functional to the maintenance of working relationships and to the support of group objectives, which are alsu shared by the individual member. In other words, "conformity is the norm and ... each individual is influenced by an awareness of the order and rank of each person in the group, and concern for what these others will think and for their behaviour' (Forss et $a .^{43}$ ).

\section{Uncertainty and ambiguity}

In view of the strict although informal rules regulating group behaviour, not only are contractual arrangements which specify tasks or areas of responsibility unnecessary but also group life is relatively predictable. At the same time, however, contractual arrangements are regarded as extremely necessary when strangers are involved and unpredictability in individual behaviour is regarded as reprehensible. All of this suggests that the Japanese tend to avoid uncertainty, an assertion which, however, conceals the very real acceptance of uncertainty and ambiguity within the group. The phenomena of official stance and true intentions would appear, moreover, to bear this assertion out. The Japanese, it seems, are willing to tolerate ambiguous situations rather than to applying strict rationalism 
and immediate decision-making. For example, within Japanese onganizations, a manager may decide to proceed even in a situation where he does not have enough information or when the outcome may be greatly influenced by other groups. He does not believe that at any one point in time that something is final and fixed but rather that one's job is to balance ambiguity, uncertainty and imperfection against one's ideals of clarity, certainty and perfection. Reischauer ${ }^{44}$ states that harmony is maintained by a subtle process of mutual understanding rather than by clear-cut decision-making. Indeed, cooperation, reasonableness and empathy are admired whilst assertiveness, competitiveness and drive are despised (Forss et al. ${ }^{45}$ ). To take this point further, the Japanese have always regarded complexity as an important dimension of reality. They have 'always seemed to lean more toward subtlety and sensitivity than to clarity of analysis, to intuition rather than reason, to pragmatism rather than theory, to organizational skills rather than great intellectual concepts' (Reischauer ${ }^{46}$ ).

\section{Work and social life}

In Japan, an emphasis is placed on social and spiritual needs as well as on productivity in the work-place. Social life plays a large part in the work-place and the Western distinction between 'work' and 'leisure' is rarely strongly upheld (Forss $e t$ $\left.a .^{47}\right)$.

\section{Harmony}

For centuries, harmony has constituted the overriding principle governing social relations in Japan, even though there are so many incompatible elements in Japanese culture. How harmony is achieved without resolution of the incompatible elements remains a moot point although it would appear that some sort of acceptable 'game-playing' or acceptable 'dishonesty' (as in tatemae and honne) is in evidence again. Forss et al. ${ }^{48}$ quote Kawashima on this point:

'In individualism there can exist co-operation, compromise, self-sacrifice, and so on, in order to adjust and reduce contradictions and oppositions, but in the final analysis there exists no real harmony $(w a)$. . . The harmony of our country is not mechanical co-operation, starting from reason, of equal individuals independent of each other, but the grand harmony (taiwa) which maintains its integrity by proper statuses of individuals within the collectivity and by acts in accordance with these statuses . . . After all, oppositions of opinions, as well as differences of interests derived from (various) standpoints, are integrated into a unity of grand harmony proper to Japan and originating from a common source. Not conflicts, but harmony is final . . .

Harmony consists in not making distinctions; if a distinction between good and bad can be made, then there harmony ( $w a$ ) does not exist.'

Let us now look at Japanese culture, thought and values in relation to the Japanese economy and the 'Japanese' management style.

\section{The Japanese economy and the 'Japanese' manage ment style}

The process of industrialization in Japan was not accompanied by the disintegration of either Japanese culture or the Japanese way of life. Indeed, policies for incorporating modern technology and modern techniques preserved both traditional organizational principles and Japanese values whilst at the same time elaborating new systems. For example, group action still manifests itself not only at the organizational but also at the national level. Companies are generally affiliated to large groupings not in terms of ownership but rather in terms of interdependence. According to Forss et al.,"

'These groupings have evolved out of the pre-War Zaibatsus, among them Mitsubishi, Mitsui and Sumitomo. The core of each such group consists of the trading company (Sogo Shosha) and/or the main bank and the most prosperous manufacturing companies. Around these key corporations, one finds a host of smaller manufacturers, suppliers and subcontractors. Group activities are coordinated at conferences where the highest ranking presidents and chairmen meet, usually on a monthly basis.'

As the industrial giants are to a large extent involved in the same business areas, competition between these groups - both at home and abroad - is fierce. In this competition for growth and market shares, profit margins have tended to be low. However, Forss et al., ${ }^{50}$ suggest that:

'Competition in Japan is not for high investment returns but for higher ranking and/or market share in the industry. In this sense, Japanese businessmen can be described as essentially "business bureaucrats" ... deriving satisfaction not so much from high profits, as from the size of their economic empires, the importance of their companies to society at large and their rate of growth.'

The large industrial groupings emphasize the pursuit of goals which are beneficial to society at large, thereby taking an appropriate place in both the domestic and world economy. The strongest organizations in the group provide security for the weaker and smaller and dynamism within the industrial structure is maintained by intra-group competition for the attainment of group objectives.

'The status of a member company is based on its industry market share and the relative size of the company within the group. The workforce itself is anxious to belong to a high-growth, high-market share enterprise since their own social ranking is highly dependent on the company' (Forss et al..$^{51}$ ).

Historically, in Japan, ownership has taken a different form from the pattern prevalent in Europe. Initially, Japan invested centrally under the initiative of government and only later were the thriving concerns sold to private interests with roots in the merchant and samurai class. These

'enterprises were by our standards heavily undercapitalized depending largely on centrally provided financing. These embryos to what is today perhaps the most competitive industry in the world, grouped themselves into zaibatsus in order to reduce risk by combining their financial resources. Maximizing growth rather than profits enlarges the business of the group bank, - which is at the core of the interdependent group companies. The pre-Worid War II banks belonged to the same zaibatsu as the corporations around it - all under the umbrella of the same holding company - therefore the question of where profits occurred was obviously less important. Today, banks and insurance companies within each group are also among the largest shareholders; in a sense depersonalizing ownership or at least widening the group of shareholders' (Forss et al. ${ }^{52}$ ).

The high debt-equity ratios in Japanese industry made organizations highly sensitive to the interest rates set by the 
central bank and thus provided government with the opportunity to influence the behaviour of industry. Although the government cannot be said to 'run' the economy, the ties between government agencies and industry have always been strong and industry has always taken cognizance of governmental opinion. This may be the result of the common social and educational background of the bureaucrats and the industrialists and the fact that these two groups have many objectives in common.

Traditionally, in Japan, the irregularities of the business cycle have been tackled either by employing a small regular staff working overtime during periods of economic upturn or by dividing the workforce into a permanent 'core' and a 'periphery' which serves as a shock-absorber during period of economic downturn. From the second decade of this century, life-time employment systems were introduced in the major companies. However, these systems comprise no more than $20-30 \%$ of the workforce. Moreover, although the principle of long-term or even permanent relations is deeply-rooted, the smaller feeder organizations on the periphery of the large industrial groups cannot afford the same privileges for their workforce as the larger and more profitable enterprises. Thus, one must constantly bear in mind - when discussing the 'Japanese' system - that the system is built on the division of core and periphery not only within the large companies but also within groupings of companies. Only three out of ten workers enjoy the privileges commonly referred to as the 'Japanese way', this figure corresponding to the union membership rate. In Japan, unions are organized by company and not by industry and tend to cater solely for regular employees. Conflicts can thus be resolved within the company, particularly as the same salary system applies to all regular workers including the management representatives at the bargaining table. Thus, even though Japanese management features are founded on similar basic principles, their actual structure tends to be company-specific (Forss et al. ${ }^{53}$ ).

The Japanese ability to pragmatically adapt to situational needs has resulted in their tackling the problems and opportunities of business organization in a number of ways, many of which may have been explained in an a posteriori fashion. In other words, the competent organizational engineering displayed by many Japanese companies may not be the result of a priori reasoning; explanations for the success of specific techniques may have rather been sought after their success has been acknowledged. What the 'Japanese management style' may have made full use of, however, is a culture that produces a highly disciplined and homogeneous workforce which superficially - at least - appears to be both harmonious and satisfied (although the true intentions behind the official stance may well have a different story to tell!). Let us, however, take a brief look at some of the facets of the so-called 'Japanese management style' both in terms of their relationship to Japanese culture, thought and values and their potential contribution to the creation of a happier and more productive workforce.

\section{The employment system}

For the 'core' employees found in any Japanese company and these, it must be remembered, constitute no more than $20-30 \%$ of the entire workforce - the organization provides life-time employment and 'allows the employees to build longterm relationships on trust ... ' (Chung \& Gray ${ }^{54}$ ). The 'coworking model' gives workers the opportunity to work together under conditions of relative security until retirement age. These employees are moved from section to section to enrich their job experience and are trained in company-specific work skills over and above the formal higher educational qualifications that most Japanese possess (Bryan ${ }^{55}$ ).

Recruits are accepted in large batches annually and these groups replace the recruits of the previous year who are moved up to a higher level. Each group is responsible for accomplishing a group task and is constituted according to the work in hand. The distribution of the work within the group is determined by the manager and each employee is expected to assist his colleagues even when their assigned tasks are different from his own. Competition between individuals is discouraged but competition between groups is regarded as 'fun' at best and as vital for organizational effectiveness at worst. Egalitarianism in Japanese organizations thus appears to apply within core groups and not between core groups; neither does it appear to apply between core and periphery workers. Amongst those who are members of the core, however, jobhopping is rare and personal career planning and training a reality. Conformity and harmony are generated by moving individuals from section to section thereby creating generalists as opposed to specialists. 'Harmonious relations are further maintained through several means such as informal communication, company organized parties and trips, consensus building decision-making, respect for the orderly status system and seniority based pay-system, as well as for the ranking order' (Forss et al. ${ }^{\$ 9}$ ). This system eliminates competition across age or status lines and encourages group responsibility and both individual and group initiative.

\section{Ranking and pay-systems}

As stated earlier, the Japanese are highly sensitive to slight differentials in pay and power. The age-grade pay system conforms with Japanese culture and values whilst at the same time allowing activities to be structured along authority lines; it also stimulates those lagging behind to try harder. Annual pay increases are given to all those core workers in the same age category and very small differentials can be introduced after the first five years. Generally, however, unequal pay only begins to function at the age of forty to fifty years after which both pay and promotion will be based on capability (Forss et al. $;^{57}$ Abegglen $^{58}$ ).

\section{The Decision-making system}

In most Western organizations, the authority of the person usually directly equals the position he holds. Authority, by implication, involves decision-making and hence responsibility; non-managerial employees are rarely consulted when decisions have to be made.

By way of contrast, in Japan, a flow of initiative and information from the lower levels of the organization upwards is encouraged. The 'bottom-up' process involves the people most involved with a problem suggesting a solution or change, the manager facilitating the use of the initiative of others (Johnson \& Ouchi ${ }^{59}$ ). Moreover, in Japan, decisions are often made through a collective decision-making process. The role of top-management is to facilitate decision-making and to maintain harmony whilst the middle manager must be an able co-ordinator and communicator (Yang ${ }^{60}$ ).

One decision-making process employed by many Japanese organizations is known as the 'Ringi system' which is a timeconsuming process whereby a proposal is drawn up in the form of a document and circulated informally within the organization. If not dismissed at any stage and returned to the pro- 
poser for revision, the document will be systematically approved by employees of successively higher rank. However, matters circulated in this way are of a relatively routine nature and the system is not particularly unique.

'What is perhaps unique is the consistency with which managers consult subordinates before a decision is arrived at by general consensus. Separating honne from tatemae... facilitates the process and is perhaps necessary for all practical reasons if consensus if to be reached. What is lost in time during these preparations is believed to be regained in faster implementation in that decisions do not come as surprises to the subordinates' (Forss et al. ${ }^{61}$ ).

Perhaps the aspect of Japanese management which has received the greatest attention in the West has been the phenomenon of quality control circles. Quality control circtes have been introduced in certain Western organizations with the main purpose of improving productivity. However, quality control circles as employed in Japan are rather different from those utilized in the West inasmuch as, in Japan, groups of workers meet voluntarily to discuss production problems and to make suggestions. Workers thus share responsib:'ity for locating and solving problems of co-ordination and productivity with management.

A quality control circle usually consists of between two and ten employees. The task of the circle - headed by a foreman, manager or supervisor - is to study any problem of production that falls within their section and to propose solutions to management. Thus, the main objectives of quality control circles are:

- the involvement of workers;

- the improvement of communication;

- higher quality products;

- job interest.

A prerequisite for the functioning of a circle is that positive and enthusiastic conditions for it must be created by management.

From this brief account of some of the main features of the so-called 'Japanese' management system, it can be seen that many aspects have perhaps been exaggerated and that others are not particularly unique. For example, the so-called 'life-time' employment system applies to no more than a small minority of core employees, a minority whose conditions of service probably differ little from those of many managers in the West. Moreover, the precise difference between the approach of some Japanese companies to employee-welfare and those employed by many Western organizations remains a moot point as does the efficacy or value of the so-called ' $R$ ingi system'. Before taking any of these arguments further, however, let us look at some of the companies which appear to be using certain Japanese management methods within the South African context with a view to assessing both their uniqueness and their efficacy.

\section{Research design}

The literature study presented above poses a number of questions with regard to the applicability of certain so-called 'Japanese' management techniques to the South African context, inter alia:

- What techniques could be employed within the South African context and which are employed?

- Of those techniques which are employed, which could be regarded as successful and which not?

- If some organizations regard certain techniques as successful and other organizations regard them as unsuccessful, what factors differentiate between the 'successful' and 'unsuccessful' companies?

- Are we in fact talking about effective organizational engineering, the human relations approach or specifically about the implementation of Japanese management techniques?

- Within those organizations employing techniques resembling those employed by many Japanese organizations, how are the role of the manager and the decision-making process constituted?

In view of both the exploratory nature of the research project and the lack of definition amongst many of the issues involved. it was decided that the most appropriate way in which to answer at least some of these questions would be to undertake in-depth interviews by means of a flexible, informal, research schedule. This schedule included the following broad areas:

- the decision-making process;

- recruitment, selection and promotion;

- job security;

- communication;

- managers and management-style;

- leadership;

- culture;

- labour unions;

- government economic policy;

- heterogeneity amongst the workforce;

- quality control circles;

- lifetime employment;

- ranking and pay systems;

- General.

The selection of organizations in which interviews could be undertaken proved rather problematic as we could acquire no accurate knowledge relating either to just how many organizations in South Africa were employing so-called 'Japanese' management techniques or indeed to just where an accurate line between 'Japanese' and 'Western' management techriques could be drawn. Ultimately, in view of the exploratory nature of the study, together with the rather strict financial constraints within which the study was being undertaken, a decision was taken to select those companies which were known to be using, or known to be intending to make use of, formal quality control circles. This decision was taken on the assumption that organizations which employ such techniques are not only utilizing methods with a definite Japanese 'bent' but also probably sensitive to other aspects of the 'Japarese' system. To this end, eight companies in various areas of manufacturing activity (for example, electrial equipment, clothes, industrial chemicals and foodstuffs) were chosen. All of these companies are familiar with the operation of formal quality control circles and are already, or are intending to use, this technique within their companies. Seven of these companies are based in South Africa and one is based in the Transkei.

In selecting individuals for interview, we spoke to thirty people employed at various levels within the organizational hierarchy who are involved with quality control circles and/or management. All the respondents were male and the interviews lasted for periods of up to two hours. All the interviews were conducted by experienced research personnel during April and May 1983.

Obviously, any research project of this type, undertaken in this way, arouses all sorts of issues relating to the generalizability of the findings beyond the response group inasmuch as com- 
plex exploratory research of this nature - with a lack of clear boundaries and definitions and a lack of a research universe - does not lend itself to quantitative techniques of data analysis. However, although no argument can be put forward for qualitative research of this nature being generalizable beyond the response group, it would appear that a study of this type can generate not only a great deal of valuable data but also a greater understanding of the phenonenon-understudy. This kind of study is, moreover, a prerequisite to the development of more quantitative research techniques which could be employed in a comparable area at a later date. The sole purpose of the current study was to generate ideas and insight on a topic of particular relevance to the South African management scene at this point in time.

\section{Characteristics of the respondents}

In all, thirty respondents representing eight companies were interviewed. Two of these companies are situated in Durban; one is involved with the manufacturing of steel products and the other is a subsidiary of a much larger organization which is involved in concerns ranging from sugar refining to the manufacturing of industrial chemicals. Of the three companies situated in the Cape, one consists of three main divisions household linen, clothing and confectionary - , the concerns of the second range from frozen meat to the production of baby food, and the concerns of the third are the design and manufacture of truck bodies. The two companies which are located in the Transvaal are concerned with the manufacture of electrical goods. The one company located in the Transkei is a subsidiary of a larger company and is concerned with textile-manufacture.

Of the thirty respondents, twenty-two were white and eight were black, and all were male. Their ages ranged from the late twenties to sixty and their job-titles from laboratory assistant and stores clerk through assistant production manager, floor manager and personnel officer to personnel manager, general manager and managing director. All were, however, involved with either quality control circles, management, or with both.

\section{Research findings}

In view of the limitations imposed by space, no more than a brief summary of the research findings is presented below. Those readers interested in a more detailed analysis are referred back to the research report (Human \& le Roux ${ }^{62}$ ), on which this article is based.

\section{Selection, recruitment and promotion}

The striking differences between the South African companies and the Japanese stereotype with regard to selection, recruitment and promotion probably result not only from the differences between Western and Eastern management systems but also the characteristics of their respective workforce. In other words, the selection, recruitment and promotion procedures utilized in a situation in which the population is relatively homogeneous, highly disciplined and well-educated are bound to differ from those employed in a situation in which the population is widely divergent, not only in terms of culture but also in terms of discipline and education. The kinds of selection, recruitment and promotion procedures employed in the case of the core workforce in Japan would appear to be applicable to no more than a core workforce with managerial potential within the South African context. Alternatively, such procedures could be adapted to meet the needs of an annual intake of lower-level employees, the majority of whom would be black. However, such procedures - which appear bound by the need for a reasonable level of homogeneity in culture, education and discipline - could never be applied to the South African workforce in toto or en bloc.

\section{Training}

Although, in the South African context, in-company training constitutes an ideal, the heterogeneity of the South African population in terms of culture, education and discipline affects the extent of its implementation. Such problems would obviously not arise amongst the relatively homogeneous core workforce in Japan.

\section{Government economic policy}

Unlike in Japan, where the ties between government agencies and industry have always been strong, the majority of South African respondents regarded government policy as 'destructive', particularly as far as race relations are concerned.

\section{Labour unions}

A variety of opinions were expressed on labour unions. On the positive side, a number of respondents argued in favour of labour unions and the role they can play in making managers aware of the workers' aspirations, values, perceptions, experiences and potential power. On the negative side, some respondents referred not only to the ability of labour unions to 'stir up trouble' but also to their tendency to polarize 'BlackWhite' relationships. The 'Transkeian' respondents expressed sentiments which are closest to reflecting the situation which pertains in Japan; that is, that problems should be dealt with within companies and not by organizations representing any particular group of workers as a whole.

\section{Security}

The research suggests that the level of job security as experienced by some workers is rather less than figures produced by management with regard to labour turnover and dismissals would appear to indicate. Moreover, the level of security experienced by the managerial staff would appear to be greater than that experienced by lower-level personnel. All of these factors in turn suggest some differences when the South African system is compared with its Japanese counterpart.

\section{Perceptions of management}

The majority of respondents felt that participatory management was the most successful kind of management and that a strong human relations component was a necessity for any organization which hopes to be successful in the Southern African context.

\section{Decision-making}

Crucial differences exist between the decision-making system employed by the organizations included in our study and that which appears to exist in Japan. Although the system employed in Japan may be neither as effective nor as efficient as portrayed by some of the more 'idealistic' literature, the system is nevertheless facilitated by a relatively homogeneous and relatively well-educated workforce. In South Africa, not only do gross discrepancies in culture and education exist, but also, and perhaps more importantly, a situation exists in which the majority of the workforce has been oppressed for a considerable period of time. In a situation of apartheid and oppression, one can hardly expect the same kind of participation in the decision-making process that one could anticipate 
in a situation of historically- and culturally-induced equality, loyalty and reciprocity. Even if an organization itself attempts to overcome many of the problems associated with colour, it can do nothing to offset apartheid in society at large, the broader socio-political context obviously having important repercussions for attempts at change within the work environment.

\section{Communication}

The communication problems within the organizations included in our research are not only complex and subtle but also exacerbated by the heterogeneity of the workforce in terms of both culture and educational level. Moreover, it would appear that quality control circles are perceived as having no more than a peripheral role within these organizations and that they are utilized generally only for certain work-related issues. It would also appear that the communication systems - both formal and informal - tend to limit communication to the level of 'official stance' and that the lower-level workers perceive themselves as having few opportunities to say what they really want to say. Whether or not this problem is also experienced in Japan is a moot point although it may well be that the Japanese tatemae belies a reality rather less harmonious than commonly assumed.

\section{Cultural issues}

The majority of respondents agreed that social interaction in organizations in which people of different races work together leads to a greater understanding between the races and to a greater empathy with regard to each other's ways. However, the respondents were also quick to point out that a multi-racial workforce leads to problems with respect to the extent to which certain customs and habits can be accommudated within the work environment. Moreover, acute communication problems exist inasmuch as management frequently finds it difficult to create understanding amongst lower-level employees. This lack of understanding is, of course, exacerbated by low levels of educational achievement and racial domination. Obviously, problems such as these are unthought of in a country such as Japan.

\section{Quality control circles}

From the accounts of the implementation of quality control circle techniques in the organizations included in our research, it would appear that the success of these techniques centres around a number of interlocking issues relating to the composition, management and functioning of the organization as a whole. The complexity and subtlety of these issues, moreover, highlights the problems involved in the implementation of such techniques as well as the extent to which techniques of this nature can create as many problems as they solve. Many of the problems, however, appear to centre around the heterogeneity of the workforce in terms of both culture and educational level, together with the lack of initiative and motivation to which political oppression can give rise. To make quality control circles work in the South African context is a far more complex and precarious task than to obtain success in a relatively sophisticated and homogeneous country such as Japan.

Some of the reasons for the failure of quality control circles would appear to include, inter alia, a lack of real commitment to techniques of this nature, production pressure, poor training in quality circle techniques, the apathy of circle leaders, lack of education amongst lower-level workers and heterogeneity of circle members in terms of rank, culture and educational level. Some of the reasons for the success of quality control circles would appear to include, inter alia, a real commitment to, and enthusiasm for, quality control circles by management, motivated group leaders, adequate training of leaders, facilitators and members, regular meetings and reasonably homogeneous groups.

In terms of these reasons for success and failure, the majority of circles with respect to which information was obtained were neither completely successful nor resounding failures. However, at the same time, it should also be stated that some were extremely successful. It would thus appear that, within very carefully defined limits, some measure of genuine worker participation and improvement in work relationships can be anticipated. At the same time, however, the odds against success could be really quite daunting.

\section{Related issues}

With respect to involvement with the group as opposed to individualism, the majority of respondents appeared to feel that group-work was only applicable to lower levels. Similarly, group remuneration and age-ranking were also felt to be more applicable to lower-level (black) employees. With regard to the concept of lifetime employment, it was felt that such a system would be viable in relation to traditional and illiterate black people but that the market was far too competitive for higher level employees not to seek job advancement elsewhere. The concept of familism, moreover, appeared to mean different things to different respondents although, in general, it was basically employed to describe a 'human relations' approach.

\section{Conclusions}

This study of the applicability of the 'Japanese management style' to the South African context has highlighted certain problems relating not only to the delimitation of that style but also its applicability to a context of cultural heterogeneity. In other words, this research questions the extent to which techniques of management which have proved successful in a relatively stable, equal, homogeneous and educated culture can be applied in a culturally and educationally heterogeneous society in which one particular group dominates the remainder. To be viable in the Southern African context, any so-called 'Japanese' method may have to undergo extensive revision. However, the problem then arises as to the extent to which any revised technique still contains the essence of its Japanese forerunner. Issues such as these are highly problematic and may merit both the time and money necessary for further research.

\section{Acknowledgements}

This article is based on a research project of the same title for which funding was obtained from the Anglo-American and De Beers Chairman's Fund Educational Trust and from ISCOR.

We would like to thank Dr M. Spoelstra for his help in the initial stages of this project and for fieldwork assistance.

\section{References}

1. Drucker, P.F. Behind Japan's success: Harv. Bus. Rev., Jan. 1981 , p.83.

2. Abegglen, J.C. The Japanese Factory: Aspects of its social organization. Glencoe, Illinois: Free Press, 1958.

3. Caudill, W. \& Scarr, H.A. Japanese value orientations and culture change. Ethnology, vol.1, 1962, p.53.

4. Yoshino, M. Japan's managerial sustem. Tradition and innova- 
tion. Cambridge: MIT Press, 1968.

5. Redding, S.G. Cognition as an aspect of culture and its relation to management processes: an exploratory view of the Chinese case. J. Manage. Stud., vol.17, 1980, p.127.

6. Bartels, R. National culture-business relatins: United States and Japan contrasted. Manage. Intnernat. Rev., vol.22(2), 1982, p.4.

7. Johnson, R.T. \& Ouchi, W.G. Made in America (under Japanese Management). Harv. Bus. Rev., vol.52(5), 1974, p.61.

8. Kraar, L. The Japanese are coming - with their own style of manangement. Fortune, vol.91, March 1975. pp.116, 160, 164.

9. Kotler, P. \& Fahey, L. The world's champion marketers - The Japanese. J. Bus. Strat., vol.3(1), Summer 1982, p.3.

10. Asakura, K. Management in Japanese Society. Managerial and Decision Economics, vol.3(1), 1982, p.16.

11. Drucker, P.F. What we can learn from Japanese Management. Harv. Bus. Rev., March - April 1971, p.110.

12. Cooper, C.L. \& Kuniya, N. Participative management practice and work humanization in Japan. Pers. Rev., vol.7(2), Spring 1978, p. 25.

13. Hatvany, N. \& Pucik, V. An integrated management system Lessons from the Japanese experience. Academy of Manage. Rev., vol.6(3), 1981, p.469.

14. Lim, H. Japanese management: A skill profile. Train. Dev. J. Oct. 1981, p. 19.

15. Cole, R. Japanese Blue Collar: The changing tradition. Berkeley: University of California Press, 1971.

16. Thurley, K. Images and attitudes of Japanese and British managers in Japanese joint ventures in the United Kingdom. Sheffield: British Association of Japanese Studies, 1980.

17. Reitsperger, W. Japanese manufacturing in Europe: Myths and realities. Fontainebleau: European International Business Association Eighth Annual Conference, December 1982.

18. Clark, R. The Japanese Company. New Haven: Yale University Press, 1979.

19. Marsh, R. \& Mannari, H. Modernization and the Japanese Factory. Princeton: Princeton University Press, 1976.

20. Johnson \& Ouchi, op. cit.

21. Pascale, R. Zen and the art of management. Harv. Bus. Rev. vol.56(2), 1978, p.153.

22. Johnson, R. Employment practices and employee attitudes: $A$ study of Japanese and American managed firms in the US. Stanford University Graduate School of Business, 1977 (Research Paper 349 EV). (See Reitsperger ${ }^{17}$ ).

23. Reitzperger, op. cit.

24. Ibid.

25. Ibid., p.13.

26. Ibid., p.14.

27. Thurley, op. cit

28. Reitsperger, op. cit.
29. Ibid.

30. Forss, K. Rolander,D. \& Kverneland, A. Some lessons from Swedish-Japanese Business Ventures. Fontainebleau: European International Business Association Eighth Annual Conference, December 1982.

31. Ibid., p.17.

32. Smedley, L.N. A sociological analysis of some aspects of the life of South Africa's Chinese community. Pretoria: University of South Africa, 1980 (unpublished D.Litt. et Phil thesis).

33. Benedict, R. The Chrysanthemum and the Sword. Boston: Houghion Mifflin, 1946.

34. Forss, et al., op. cit. p.19.

35. Ibid.

36. Moore, C.A. The Japanese Mind. Honolulu: University Press of Hawaii, 1967, p.289.

37. Forss, et al., op. cit. p. 20

38. Moore, op. cit.

39. Forss, et al., op cit. p.23.

40. Ibid.

41. Ibid.

42. Ibid., p. 26 .

43. Ibid., p.28.

44. Reischauer, E.O. The Japanese. Cambridge: Harvard University Press, 1977

45. Forss, et al, op. cit. p.28.

46. Reischauer, op. cit. p.226.

47. Forss, el al., op. cit. p. 29

48. Ibid., p.30

49. Ibid., p.31.

50. Ibid., p.32.

51. Ibid., p.33.

52. Ibid., p.33.

53. Ibid.

54. Chung, K.H. \& Gray, M.A. Can we adopt Japanese methods of human resources management? Personnel Administrator. vol.27(5), May 1982, p.42.

55. Bryan, L.A. Jnr. The Japanese and the American First-Line Supervisor. Train. Devel. J. January 1982, p.62.

56. Forss, et al., op. cit. p. 38 .

57. Ibid.

58. Abegglen, op. cit

59. Johnson \& Ouchi, op. cit. p.62.

60. Yang, C.Y. Management styles: American vis-d $\alpha$-vis Japanese. Columbia Journal of World Business, Fall, 1977.

61. Forss, et al., op. cit. p.41.

62. Human, L. \& Le Roux L. The applicability of the 'Japanese Management Style' to the South African context: Preliminary Research. Pretoria: University of South Africa, School of Business Leadership, 1983 